\title{
Keskusteluavaus tunteiden merkitykseen aikuisten oppimisessa
}

Juha Varila (1999). Tunteet ja aikuisdidaktiik-ka. Tunteiden aikuis-didaktisen merkityksen teoreettinen ja empiirinen jäljitys.

Joensuun yliopisto. Kasvatustieteiden tiedekunnan tutkimuksia N:o 74. $161 \mathrm{~s}$.

\section{Tunteet ovat vähitellen} nousemassa keskeiseksi tutkimuskohteeksi modernin rationaaliseen ajatteluun kasvaneiden ihmisten mielissä. Tunteiden tarkastelu on samalla sekä virkistävää että haasteellista. Virkistävää niiden tarkastelu on siksi, että moderni aika on painottanut pelkästään laskelmoivaa ajattelua ja loogista, viileää, etäistä katsetta. Juuri samasta syystä niiden tarkastelu on vaikeaa. On vaikeaa murtautua irti modernin ajan loogisesta ja erittelevästä ajattelusta, jossa tunteetkin möyhentyvät laskennallisiksi malleiksi ja järjen avulla suoritetuiksi erittelyiksi.

\section{Juha Varila aloittaa}

kiinnostavan tutkimuksensa

pyrkimällä tarkastelemaan

työniloa kasvatustieteellisenä ilmiönä. Hän on ikään kuin epäsuorasti ajautunut havaitsemaan, että tunteet ovat kasvatustieteessä lähes tutkimaton alue. Varila päätyi tämän havainnon tehtyään viisaasti tarkastelemaan tunteita.

Hän tarkasteleekin sitä, tunnetaanko aikuiskasvatustieteessä tunteita. Hän tarkastelee aihettaan kasvatustieteellisten tutkimusten kautta.
Hänen kasvatuksen teorioista käyttämänsä luokittelut "puutarhurimääritelmiin” ja "muottimääritelmiin" ovat kuvaavia sekä osuvia. Myös hänen kasvatustieteellisen tutkimuksen rationaalispainotteisuutta vastaan kohdistamansa kritiikki on osuvaa.

Tässä tarkastelussa tahtoo unohtua kasvatuksellisten toimenpiteiden osallistujissa mahdollisesti aiheuttama ahdistus, pelko ja epätoivo. Varilan johtopäätös, jonka mukaan taloustieteellinen, rationaalisen valinnan teoria on siirtynyt aikuiskasvatuksen ihmiskäsityksen osaksi, on herättävä.

\section{Kolmannessa luvussa} Varila väittää, että merkityksellisessä oppimiskokemuksessa tunteet ovat mukana. Väitteensä tueksi Varila on kerännyt empiirisen aineiston, joka koostuu 60 kasvatustieteen avoimeen yliopisto-opetukseen osallistuneen opiskelijan kahteen esseekysymykseen tekemistä vastauksista. Monet Varilan saamista tuloksista ovat herättäviä. Poimin tähän joitakin: "Useimmat merkitykselliset oppimiskokemukset ovat tapahtuneet virallisen koulutusjärjestelmän ulkopuolella... Valtaosa seurauksiltaan kielteiseksi arvioiduista kokemuksista on tapahtunut virallisessa koulujärjestelmässä... Huonosti sovellettuna millä tahansa opetusmenetelmällä kyetään aiheuttamaan kielteinen oppimiskokemus."

\section{Varilan tutkimus}

korosti myönteisen, empaat- tisen vuorovaikutuksen merkitystä ja ihmisen oman henkisen kasvun avartumisen merkitystä myönteisille oppimiskokemuksille. Vastaavasti kielteisille oppimiskokemuksille oli tyypillistä nolaava, nöyryyttävä vuorovaikutus ja halveksituksi tulemisen tunne. Varila päätyykin toteamaan, että tunteilla tulisi olla aikuiskasvatuksessa keskeinen sija.

\section{Neljännessä luvussa}

Varila tarkastelee tunteiden käsitettä eri teorioiden ja koulukuntien avulla. Käsitteiden erittely on kasvatustieteen perinteen mukaista. Samalla tekijä tietenkin joutuu itsekin modernin rationaliteetin sisälle erittelemään viileästi käsittelemäänsä aihetta. Erittelynsä tuloksena kirjoittaja päätyy esittämään tunteiden synnyn kaksi polkua, hitaan- ja nopean polun. Hitaassa polussa havainto tulkitaan kognitiivisesti ennen tunteen muodostumista. Nopeassa polussa ärsyke liittyy suoraan fysiologisiin muutoksiin ja tunnepurkaukseen ja vasta tämän jälkeen kognitiiviseen tulkintaan. Varila ei liitä rakentamaansa mallia osaksi psykodynaamisia näkökulmia. Niinpä lukijalle jääkin epäselväksi, missä määrin nopea polku on sama kuin puolustautumismalli (defensi). Nyt esitetty malli on analyyttinen ja rationaalisten vaiheiden kautta etenevä. Lukija ei voi välttyä ajatukselta, että aihetta tulisi edelleen tutkia.

\section{Viidennessä luvussa}


Varila käsittelee ilon käsitettä $\mathrm{mm}$. Spinozan määritelmiin nojautuen. Luku poikkeaa hieman Varilan valitsemasta teemasta käsitellä tunteita ja jäsentyy ikään kuin alkuperäisen työnilon tarkastelupyrkimyksen kaikuna. Lukua olisi voinut elävöittää nykyistä laajemmalla filosofian tarkastelulla esim. ottamalla fenomenologia ja fundamentaaliontologian näkökulmat tunteiden tarkastelun perustaksi. Toinen vaihtoehto olisi ollut liittää tunteiden tarkastelu psykologiseen viitekehykseen. Myös sosiaalinen konstruktivismi ja ns. kriittinen psykologia olisivat voineet tarjota kiinnostavia virikkeitä käsittelyyn.

\section{Analogisesti aloittamal-}

leen ilon kokemisen tarkastelulle tekijä käsittelee ilon kokemusta myös empiirisesti. Tutkimusaineistona tekijällä on 62 opiskelijan esseevastaukset. Tekijä ei ole eritellyt esseiden kielellisiä strategioita kuten sitä, että opiskelija on kirjoittanut ne opettajalleen, aikuiskasvatustieteen professorille. Esseiden universaaliyleisö ei ole siis kuka tahansa vaan nimenomaan auktoriteettihahmo. Muutoinkin esseiden sisällön kuvailu on suoritettu varsin pelkistetysti esim. tekemällä taulukoita ilon aiheuttajista. Ilon aiheuttajat on repäisty irti kontekstistaan ja liitetty taulukossa kolmiluokkaiseen tarveskaalaan. Kun vielä tulokseksi saatiin, että suurin osa ilon kokemisen aiheuttajista liittyy yhteisyyskokemuksiin, voitaneen ainakin sosiaalisen konstruktivismin viitekehyksestä kysyä, mitkä aikuiskasvatuksen tapahtumat eivät ole sosiaalisesti konstruoituneita?

\section{Vaikka ilon aiheuttajien}

tyypittelystä voitaneen olla monta mieltä samoin kuin tekijän tavasta nostaa esille tutkimuksensa tuloksia, voitaneen tekijän esittämiä tuloksia pitää vähintäänkin osuvina. Tekijä kysyykin, onko opetuksemme didaktisessa toteutuksessa jotakin pielessä, kun opiskelu ei ole tuottanut ilon kokemuksia? Tähän kysymykseen voinee itse kukin ottaa kantaa ja peilata omia kokemuksiaan oppimisen ja opetuksen kentässä.

\section{Kirja kysyy joka}

tapauksessa osuvalla tavalla kysymyksiä, jotka vaativat vastausta. Ehkä vastausta tunteiden merkityksestä aikuisdidaktiikassa ei saada yhden kirjan puitteissa, mutta yksikin kirja voi toimia keskustelun avauksena. Varilan tutkimus on juuri tällainen keskustelun avaus. Ehkä tekijä on sen sellaiseksi myös aikonut, sillä hän päättää tutkimuksensa toteamukseen, että "aikuisdidaktisen tutkimuksen olisi löydettävä uusi sävel." Voinee vain toivoa onnea tällaisen uudenlaisen sävelen etsimispyrkimykselle, siksi tärkeitä ovat tunteiden tarkastelu ja kasvuun liittyvien ilon kokemusten etsiminen.

Pauli J uuti 